\title{
Potential role of HIV-1 Nef and human M6B in HIV-associated neurological disorders
}

\author{
Jessica Moetter ${ }^{1 *}$, Silke Hoffmann ${ }^{1}$, Esther Jonas ${ }^{2}$, Dieter Willbold ${ }^{1,2}$ \\ From $16^{\text {th }}$ International Symposium on HIV and Emerging Infectious Diseases \\ Marseille, France. 24-26 March 2010
}

\section{Background}

"Highly active antiretroviral therapy" (HAART) has dramatically increased the life expectancies of HIV positive humans. Due to this progress, other HIV-infection associated consequences like the HIV-associated neurological disorders (HIV-ND) are becoming more and more significant. The HIV Nef protein seems to play an important role in progression of HIV-NDs. We set out to identify brain tissue specific ligands of membrane associated Nef.

\section{Methods}

We applied a membrane associated yeast two-hybrid "split-ubiquitin" based system to identify human brain tissue specific proteins as direct ligands of HIV-1 Nef. Positive hits were confirmed by co-immunoprecipitation assays (CoIP), pull-down analysis, confocal microscopy and fluorescence titration assays.

\section{Results}

From a cDNA library of human brain tissue we identified the neuronal membrane glycoprotein $\mathrm{M} 6 \mathrm{~B}$ as a novel binding partner of Nef. Relevance of the Nef-M6B interaction was confirmed by CoIP assays in yeast and pull-down analysis using rat brain extracts. Association of Nef with M6B was supported by confocal microscopic studies in Neuro-2A cells. Co-localisation of transiently expressed Nef-DsRed with endogenous M6B or transiently expressed GFP-M6B was found. Direct interaction between Nef and M6B could be demonstrated by fluorescence titration studies using recombinant Nef protein and M6B derived peptides. We found that the Nef binding determinant of M6B is contained in its cytoplasmic

* Correspondence: j.moetter@fz-juelich.de

${ }^{1}$ Forschungszentrum Juelich, ISB-3, Structural Biochemistry, 52425 Juelich, Germany loop that is conserved among proteins of the PLP family.

\section{Discussion}

Nef binding to M6B and other members of the PLP family might interfere with function and/or localisation of the respective protein leading to severe consequences for the function of HIV infected cells. Our results are discussed with the known benefits of SRI (serotonin reuptake inhibitor) treatments or the synergistic proinflammatory and neurotoxic effects of exogenous opiate drugs during HIV infection.

\section{Author details}

${ }^{1}$ Forschungszentrum Juelich, ISB-3, Structural Biochemistry, 52425 Juelich, Germany. ${ }^{2}$ Heinrich-Heine-Universitaet Duesseldorf, Institut fuer Physikalische Biologie, 40225 Duesseldorf, Germany.

Published: 11 May 2010

doi:10.1186/1742-4690-7-S1-P18

Cite this article as: Moetter et al:: Potential role of HIV-1 Nef and human M6B in HIV-associated neurological disorders. Retrovirology 2010

7(Suppl 1):P18

Submit your next manuscript to BioMed Central and take full advantage of:

- Convenient online submission

- Thorough peer review

- No space constraints or color figure charges

- Immediate publication on acceptance

- Inclusion in PubIMed, CAS, Scopus and Google Scholar

- Research which is freely available for redistribution

Submit your manuscript at www.biomedcentral.com/submit
Biomed Central 